\title{
Fish Tales: Local Fishing in the Kingdom of Tonga
}

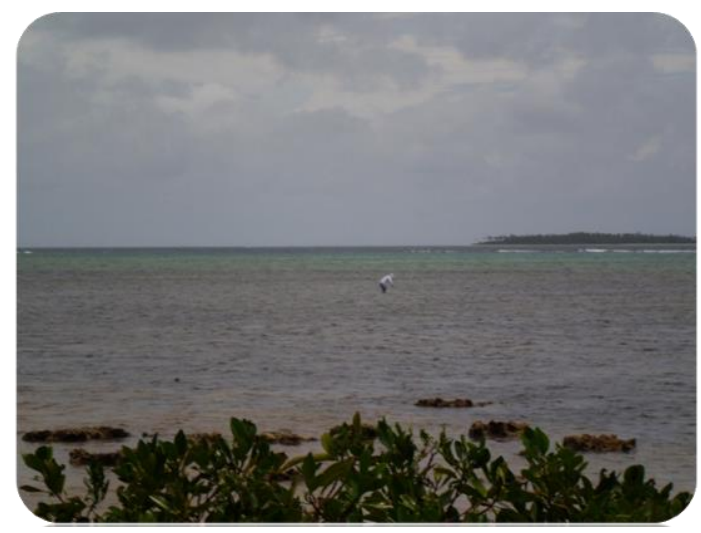

\section{Abstract}

In the small island developing state of Tonga, an archipelago of 176 coral atolls scattered across 664,853 square kilometres of the South Pacific Ocean, power and resourcing differentials dictate which people are permitted to be commercial fishermen and what groups do the subsistence kind, customary fishing. A handful of Native Tongans engage in commercial exporting. The tuna industry is dominated by foreign vessels, by foreign countries, that can afford the state fishing license and the operation costs.

The Government of Tonga has confined coastal communities to customary fishing as the sustainable development model, a solution beset with tension. There is resource scarcity of inshore fishing stock. When local

Teena Brown Pulu has a PhD in anthropology from the University of Waikato. She is a senior lecturer in Pacific development at AUT University. Her first book was published in 2011, Shoot the Messenger: The report on the Nuku'alofa reconstruction project and why the Government of Tonga dumped it. 
fishermen are denied access to deep sea commercial fishing their chances at exporting and making profit are limited, tempting some to poach undersized stock and pressure the government to remove conservation sanctions on species at risk of depletion. What options for livelihood from the sea do coastal communities have? Related to this, what tensions emerge between the Tongan state and coastal communities wanting to be included in the commercial fishing industry?

\section{In memory}

We cannot trample upon the humanity of others without devaluing our own.

\section{Chinua Achebe}

There was little fish in Tonga being sold at the Nuku'alofa waterfront compared to yesteryear. When I was a child, my half-caste mother who was born in Tonga would put me on a flight from Auckland to spend school break with her older sister. For the entire summer holiday, a month at our family homestead in Havelu'loto, I felt bored to tears with books to read, the piano to play, and the dog for company. I was named after my aunt, Tina Brown; my mother changing the spelling of my name to Teena Brown because it was modern and trendy. As a New Zealand kid visiting my aunt in Tonga, outings which pleasantly interrupted the monotony of being kept home were spent looking at seafood stalls on the roadside, at the market in town, and by the waterfront along the wharf.

In Tonga people trapped fish on the foreshore, trawled in the ocean, gathered shellfish in the reef, crabs in the swamp, jellyfish in the lagoon, selling the product of their labour. I thought it was impressive, envious that I was not part of this everyday life industry of being an islander with skin browned by the sun and galvanised by the sea. People looked physically durable, mentally resilient, and happy. Even if the 
children my age that I saw manning stalls toiled hard, the display of ware was the ocean's bounty with cash in pocket for sales.

Through the limits of my experience as a child of part Tongan, part Palangi ancestry, born and raised overseas, one who holidayed in the old homeland at a comfortable family abode, I cultivated a romantic impression. I carried it with me to adulthood. In memory, Tonga's ocean was an extension of fertile land, a garden of fish and seafood, lavish and plentiful. The island Kingdom of Tonga, "where the people are nice, their hearts are full of smiles. Arch you back in time, beautiful days of my life" (Kamali, 2011).

Late January of 2013, I arrived in the Kingdom of Tonga to hunt-and-gather fish stories. To explain, I wanted to learn what happened to the local fishing industry. In December of 2011, Tricia Emberson, the former general manager of 'Alatini Fisheries Company Limited, put her business into voluntary liquidation. Local newspapers attributed her as saying that Tonga's fishing industry was dead (Matangi Tonga Online, 2011b). Whether this was an accurate statement, or one that the media figured would sell, was peripheral to the storyline. The bait was that since 1989 Emberson, an ex-patriate New Zealander, a white woman, had built up a company that exported fish to New Zealand employing local labour in her Tonga based operation. Reports that the fishing industry was dead and 'Alatini Fisheries buried, drew public attention to how hard it was to commercially fish and stay afloat. 


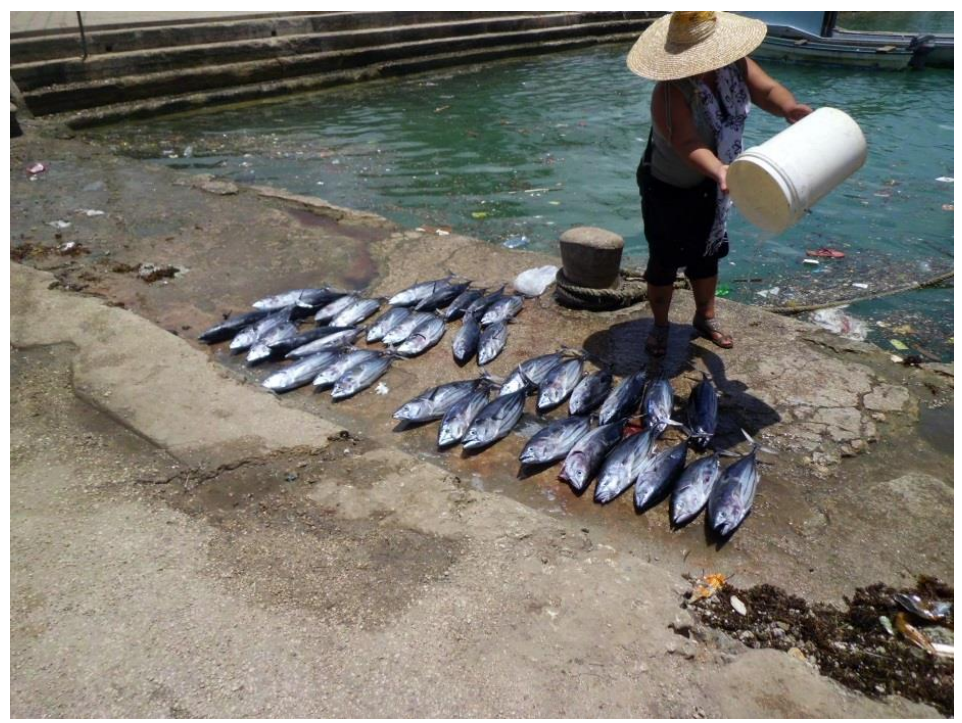

A Tongan woman selling a fresh catch of fish alongside the Nuku'alofa waterfront in the Kingdom of Tonga.

\section{Foreign sharks}

In 1998, Emberson wrote a workshop paper for a fisheries report compiled by the Food and Agricultural Organization of the United Nations (FAO). Over a decade before liquidation, she highlighted the tension that existed between the Tongan state and the country's privately owned commercial fishing companies. Her fledgling business ran into road blocks when it first tried to break into the tuna and bottom-fishing market in 1993. "Alatini's entry into tuna was not welcome," she recalled. It happened that "in Tongan waters, a majority government-owned 'private' company, Sea Star Fishing Company Limited" held exclusive management rights over tuna long-lining (Emberson, 1998, p. 51).

The foundational period for the Government of Tonga to deregulate the commercial fishing industry was the public sector reform years of the 1990s. Public sector reform is the 
brainchild of Western desire. It represents the financial aspiration of developed countries that growth and profit will materialise from integrated economies based on free market trade between countries and across regions. The reform rationale is for the state, the government of a country, to release much of its business to private companies. In theory, by growing a powerful private business sector, a country will profit financially because more jobs will be created for citizens and more money will be circulated locally.

Western countries had read economic theory to do with trade liberalisation as truth, not that this was automatically absorbed as universal good sense by the rest of the world. As Emberson noted, in a non-Western small island developing state such as Tonga, there was resistance to opening up space in the private sector for newcomers, for foreign investors like herself. Expressly, foreign investors who were not Tongan citizens by birth in this country, who were not Tongan by blood, by ethnicity, by parentage, by ancestral descent, were not socially accepted as having or deserving equal rights of belonging and entitlement as real Tongans who measured up to the identity benchmark.

Tonga, in many ways, continues to be a closed society organised by hierarchy, bloodlines, kinship loyalties, and patriarchy. The idea that business is a free-for-all activity where any person, from any country, can step-foot inside this class and kin based society to access its limited wealth for their own financial gain and status, stands in direct opposition to convention, tradition, and established norms of social and economic exchange.

Sea Star Fishing Company Limited was a Tongan state owned and operated quasi-public enterprise engaged in private business. As a local competitor, Sea Star had the competitive edge in the commercial fishing industry by the privilege of having exclusive rights over tuna. This was to become the public sector business model for functioning in a deregulated economy. What Emberson described in 1998 as "a majority 
government-owned 'private' company" is, in 2013, the established organisational behaviour for 16 public enterprises, 8 of which operate at a financial loss. To restate, in presentday Tonga, half of the state's businesses cost the Tongan taxpayer more money to operate than what is generated in revenue.

Brunsson and Sahlin-Andersson clarified that public sector reform can be manoeuvred by governments to contravene the idea of freeing up the business sector to take over the function and financial power of the state. In this sense, the state can use structural reform processes to strengthen their business organisations under principles that freeze and preserve the top-down mentality of "local identity, hierarchy, and [state-owned] rationality" (Brunsson and Sahlin-Andersson, 2000, p. 721).

Recent public-sector reforms can be interpreted as attempts at constructing organizations. Public-sector entities that could formerly be described as agents or arenas have been transformed into 'more complete' organizations by installing or reinforcing local identity, hierarchy, and rationality. This interpretation helps explain important aspects of the reform process. (Brunsson and Sahlin-Andersson, 2000, p. 721).

The authors' description of public sector reform contains a type of truth for the Kingdom of Tonga in that the government competes in, and towers over, the private sector as stateowned companies. Indicative of a Pacific Island state economy, the Government of Tonga is the country's largest employer and has a stronghold over businesses tied to national infrastructure and information. Tonga Broadcasting Commission, Tonga Water Board, Tonga Power Limited, Ports Authority Tonga, Tonga Airports Limited, Tonga Communications Corporation, and Tonga Development Bank are but half of the nationalised commercial entities. 


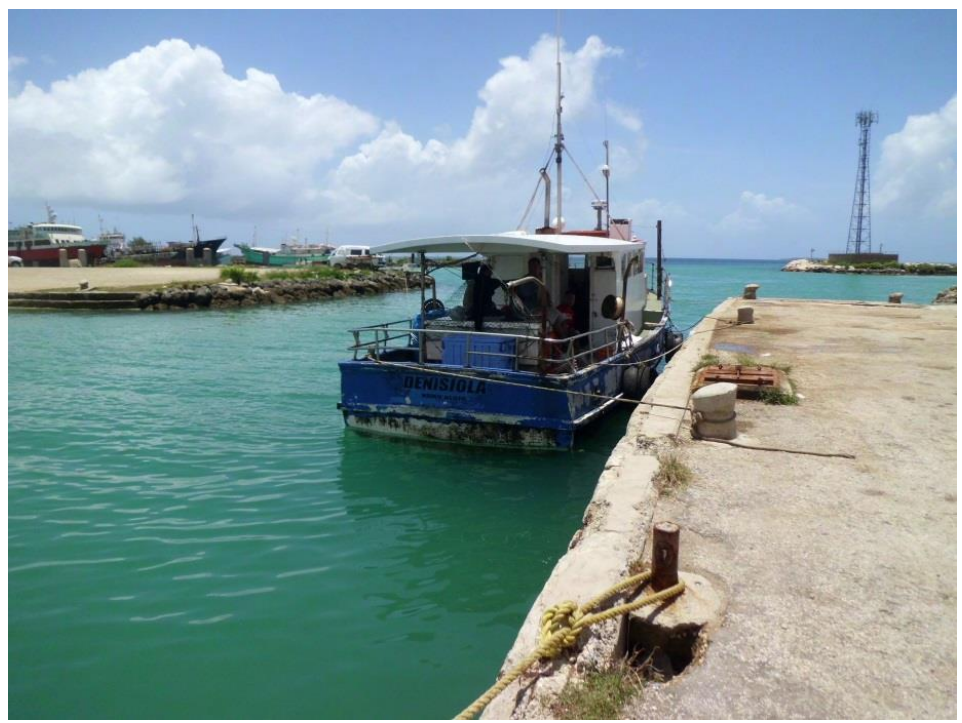

A Tongan fishing boat docked at the Nuku'alofa waterfront in the Kingdom of Tonga.

Complexly, there was collaboration among an insular elite group of private businessmen, and the odd businesswoman, in relation to Tonga's public enterprises which played out in the membership of boards. One male director sat on three different boards; one male was the chair of one board and a director on another; one woman sat as a director on two different boards; one board had two brothers working as the chair and a director; and there was an uncle and his nephew working as the chairmen of two different boards. If ever there was a small island case for conflict of interest, or rather, that the interests of a few mattered more than the masses when ruling the Kingdom's business powerhouse, then Tonga was a strong contender (Tonga Government Portal, 2013).

In saying this, there appeared to be little sign that the 2010 - 2014 government headed by Prime Minister Lord Tu'ivakano intended to downsize the state bureaucracy. In fact, the political landscape signalled that the Tu'ivakano 
administration was increasing state-owned businesses. Talk within the public service murmured that the Tonga Energy Road Map, the 2010 - 2020 national renewable energy project bankrolled by aid donors, was going to be instituted as a public enterprise. As well, a government newspaper was initiated in May of 2012 competing alongside six independent newspapers (Pacific Media Centre, 2012). From inside the media industry, criticism surfaced: The government rag ran at a financial loss. But the state claimed it required a paper to publish public notices, and so it stayed.

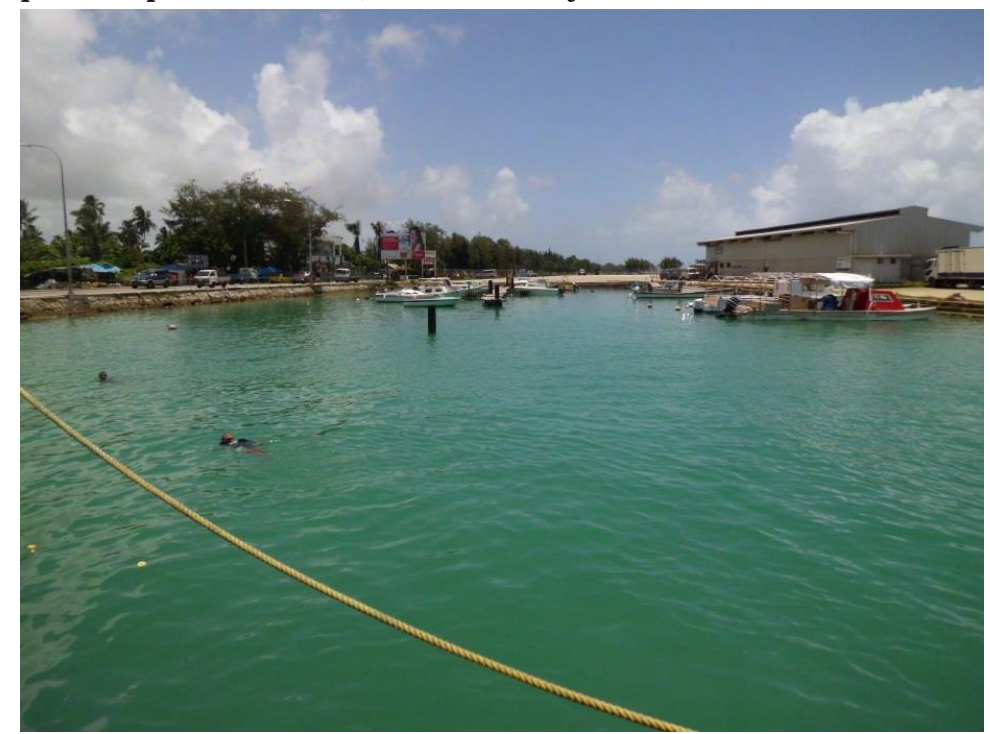

Tongan boys swimming in the boat marina at the Nuku'alofa waterfront in the Kingdom of Tonga.

In 1998 Tricia Emberson wrote that "most countries welcome overseas investors to help boost the Nation's economy and standard of living. They usually encourage investment by offering tax holidays, duty free concessions etc to attract investment in certain important industries" (Emberson, 1998, p. 54). Her experience in Tonga, however, was somewhat to the contrary. Twenty two years hard labour developing a 
company, she left the industry in 2011. Local media recorded that the state tax regime held over private businesses, the exploding costs of fuel, processing, transhipping, and air freight, compounded by successive governments which "were not particularly committed to the growth of the fishing industry," gave her little option but to exit (Emberson, 1998, p. 52; Matangi Tonga Online, 2011b).

Was this the tail end of the 20th century white foreign investors from New Zealand and Australia persisting to stay on in 21 st century Tonga? Perhaps it signalled a new age of Chinese foreign investors occupying the business sector. The truth was 'Alatini Fisheries Company Limited was not completely undone, but reworked into a new business called Kool Fresh which was one of two registered companies in Tonga to hold a state license to fish tuna. Added to Kool Fresh Imports and Exports, Tricia Emberson owned a liquor store and a bar, diversifying her business reach and scope in Tonga. My point is by no means was this white woman in Tonga thrown in the poorhouse. Emberson's account of the foreign investor single-handedly battling to trade in a small island Kingdom obsessed with counting coconuts instead of fish, (where she argued in her 1998 paper that the government favoured agriculture over fisheries), struck a chord with the 2013 International Monetary Fund's (IMF) helpful business tips for Tonga.

From Washington DC, the International Monetary Fund (IMF) sighted the Kingdom of Tonga as a small remote country. On its 2013 mission to the capital of Nuku'alofa, the IMF narrated the modern economic history of my ancestral homeland. The Native population was expected to believe, resay, and in the process, internalise the story created about us as the truth; an authoritative truth of what important people in the capital of the United States of America think is wrong with us down here south of the equator. To its advantage, the islands possessed "a well-educated, English speaking populace," said the IMF, ticking this off as a good- 
looking feature to foreigners. An unfortunate circumstance of being a group of islands in the remote south was getting wedged in "a low development trap." A standard cure was prescribed for Tonga's poor financial health; "structural reform" through "foreign investment" (International Monetary Fund, 2013).

Tonga is battling a low development trap, which is aggravated by its smallness and remoteness. Vast marine resources, the potential to grow niche tourism, and a welleducated, English speaking populace, point to a potential for Tonga to break this limit. But this will take further deepening of structural reform. Breaking away from the trap will require a big push in private investment. However, Tonga's business environment needs to be made more conducive to attracting foreign investment. (International Monetary Fund, 2013).

The International Monetary Fund advised the Government of Tonga to make the business sector open game fishing for outsiders with money to come in and fix the place. In the words of Kai Davis, for the Native Tongans this top-heavy worldview of our islands from below ensures that "my people don't even know that we are working with our oppressors; just passing on the torch when we can't pass the bar because the bar has been set so low, we are crushing under the weight" (Davis, 2012). What I am saying is that a peculiar kind of racism is harvested from the low expectations that First World countries maintain over and about the poor coloured nonwesterners of the Third World.

Partha Chatterjee explained this point in his book, The Nation and Its Fragments (1994). He argued that the collective purpose of developed countries in world politics is to dominate how developing states think and behave so they cannot imagine themselves as progressing along the lines of any alternative to Western European and North American models 
of development. A precise method of controlling the social imagination is executed. Rewriting history is the process that indoctrinates non-western peoples into believing that "Europe and the Americas" are "true subjects" vital to international affairs, while the developing world is peripheral, small, insignificant, and of little material and intellectual value to any world leader, to any country of great wealth and status (Chatterjee, 1994, p. 5).

If nationalism in the rest of the world have to choose their imagined community from certain "modular" forms already made available to them by Europe and the Americas, what do they have left to imagine? History, it would seem, has decreed that we in the postcolonial world shall only be perpetual consumers of modernity. Europe and the Americas, the only true subjects of history, have thought out on our behalf not only the script of colonial enlightenment and exploitation, but also that of our anticolonial resistance and postcolonial misery. Even our imaginations must remain forever colonized. (Chatterjee, 1994, p. 5).

Similar to the IMF diagnosis, the Asian Development Bank (ADB) gave Tonga a repeat dosage of "structural reform" as the antidote for "debt distress" caused by a "weakened economy" (Asian Development Bank, 2013). The ADB remedy came with the not-so-friendly message that this is what the doctor ordered. What this meant is that aid donations and bank loans were given to Tonga with strict conditions. The regional policy regime promoting integration through foreign investment and trade liberalisation demanded compliance. Tonga had to toe the line and open up its closed borders to foreign business.

Given Tonga's high risk of debt distress, the consolidation needs to be appropriately paced to avoid 
further contraction in an already weakened economy. ...The government needs to maintain its implementation of structural reforms. These are central to the joint policy reform matrix for budget support agreed to with development partners. (Asian Development Bank, 2013).

It was all about Captain Cook's Friendly Islands of Tonga becoming a "business friendly" port of call "for foreign investors," echoed the IMF (International Monetary Fund, 2013). The US money and power broker was telling poor countries how to survive as bottom-feeders in the modern world system governed by America and Western Europe (Arrighi, Ahmad, and Shih, 1999; Wallerstein, 1990).

Reforms focusing on policy coordination and deregulation are needed to unshackle private sector initiative. The mission appreciated various initiatives and progress for nurturing a business friendly environment, particularly for foreign investors, and discussed with the authorities the way forward, including in strengthened policy coordination and a deepening of business licensing reform. (International Monetary Fund, 2013).

\section{Troublesome tuna}

A deep-seated contradiction kept resurfacing every time the Government of Tonga tried to obediently reform under the reformers who wrote the book; that is, according to the economic growth findings of costly consultancy reports compiled by the IMF, the ADB, the World Bank, and the aid donors of developed countries namely from the European Union (EU), AusAID, and NZAid. In Tonga's case when "a deepening of business licensing reform" was applied to the tuna industry from $2011-2013$, the Tongan state copped flak from the outside general public and inside its own 
bureaucracy. Tuna was troublesome; it allured foreign boats into Tongan waters which made the locals uneasy.

In October of 2011, the government collapsed the 2004 moratorium prohibiting foreign bottom-fishing vessels in Tongan waters. The Tonga Fisheries Department opened up the exclusive economic zone for business, selling tuna long lining licenses to foreign vessels predominantly from Taiwan at USD $\$ 20$ thousand dollars per annum. There was public opposition to this decision. Critics of the state protested that local fishermen were denied access to a potentially lucrative industry which should prioritise Tongans first and foremost over foreigners. The government rationale of resuscitating a dying industry by stimulating foreign investment was ridiculed as counter to the economic welfare of Tongan nationals.

Fishing is the only commodity and main food source for our people. How can giving licenses to foreigners to exploit our sea water with their selfish mass fishing help revive the fishing industries in Tonga and benefit our own people? If they can fish and sell globally then so can our own people. Why can't the government get a fishing boat of its own and employ locals to operate it? How about working on setting up a canning factory for the locals' catches and tap on the regional and global fishing market? Don't say there is not enough money because Tongan government officials travel lavishly as if the Friendly Isles are floating on a sea of gold. Come on Tonga! (TNews, 2011).

Fifteen months into selling what was officially termed the "locally based foreign fishing vessel licence," Sangsta Saulala, Tonga's Minister for Agriculture and Fisheries gave his New Year message of January 2013; a heftier push to resurrect commercial fishing was in motion. Saulala's government had "signed a memorandum of understanding (MOU) with 12 foreign fishing boats, allowing them to fish in Tonga's Exclusive Economic Zone (EEZ) for a year, for a fee of about 
[USD]\$154,000" (Matangi Tonga Online, 2013). "The agent in Tonga for" the vessels were named as "Lisiate Hui Chin Chen and Mosese Fakatou" (Kingdom of Tonga, 2011). At that price, a discount had been given on the original 2011 fee of USD\$20 thousand dollars for one year's fishing. One license would now cost each of the twelve vessels under the MOU a sum of USD $\$ 13$ thousand dollars. Inside Tonga's 664,853 square kilometre zone were twenty four vessels at work with tuna licenses, the majority being foreign trawlers with two local companies.

Pesi Fonua, publisher of Matangi Tonga, was quick to point out that this tuna licensed fleet along with other foreign vessels would not be sourcing local labour to process and tranship their catches for export. The public criticism he stressed was that at a cheap rate of USD $\$ 154,000$ per annum for twelve Asian boats, the government and the people of Tonga were getting ripped off.

Most of these foreign fishing boats will ship their catches straight overseas, and will not need any supporting services from any local sources, because the local infrastructure do not have the capacity to meet their demands. Therefore depriving government and Tonga, some argued, millions of pa'anga. Those who are against the move by government to issue 'cheap' tuna fishing licenses to foreign fishing boats argue that the license fees that government is getting are 'a tear drop in the ocean.' (Matangi Tonga Online, 2013).

Factors propelling the disgruntlement that the sale of foreign licenses was not economically viable, nor was it sustainable business, had been erased from Tongan media. This may have been an oversight or a deliberate choice not to print. In Tonga, the media industry operates in a politically volatile environment divergent to developed countries. Accustomed to navigating through high risk in a small society, 
Tongan media requires a different skills set for reporting in a small country where people with power in the public eye are known, have relatives and friends in high places, and have the capacity to exert the kind of influence that can cut a journalist, an interviewer, a researcher, out of the information loop and out of work. The reality is that controversial news items can potentially ignite state surveillance over independent publishers, which is an intimidation tactic to sift out the friendly islanders from the anti-government press.

Omitted from public scrutiny were details about the "locally based fishing vessel licence" authorised by the "Minister of Fisheries" under "The Fisheries Act 1989 (Regulation 28)" relevant to the sustainable management of fishing stock (Kingdom of Tonga, 2011).

Authorised Target Species: Tuna Species (Albacore, Bigeye, Yellowfin, Skipjack)

Authorised Quota (where applicable): Not Applicable (Kingdom of Tonga, 2011).

The license allowed vessels to catch an unlimited quota of tuna. From the five species of tuna, Southern Bluefin was not permitted in catches due to severe depletion from overfishing (Harvey, 2013). But despite Yellowfin being identified on the International Seafood Sustainability Foundation's (ISSF) list of overfished tuna species, the Minister of Fisheries signed it off as a legitimate catch in Tongan waters. Crucial questions squatted uncomfortably around state regulation. How would the Government of Tonga enforce state control over sustainable fisheries management and fair-trade without setting a quota on catches? Without the state monitoring catches to ensure that overfishing and the fishing of proscribed species does not take place in Tonga's EEZ, how is sustainable fisheries management practical? Without the Ministry's Fisheries Department collecting and analysing data 
on the commercial fishing impact on tuna stock, how is sustainable fisheries management conceivable?

Bill Fox and Dale Squires asserted the position on tuna management of the International Seafood Sustainability Foundation (ISSF), endorsing the 2010 Bellagio Framework calling on countries to decrease tuna vessels fishing inside their EEZ (Fox and Squires, 2012; Bellagio Framework, 2010; Grafton et al, 2010). Tonga had either missed the boat on scientific research findings informing regional policy on tuna sustainability, or perhaps, had forfeited research-driven policy for an undersized catch of USD\$154,000 for a dozen licenses. A business scenario not voiced in Tongan media and public criticism are acts of political diplomacy between Tonga and Asian aid donors, particularly China. Multiplying the Government of Tonga's Look to the East foreign policy, the growth of Chinese businesses in Tonga's private sector, and the exchange of China aid by way of financial assistance and free gifts such as the two MA60 aircraft, the possibility could not be ruled out that tuna licenses marked-down to sale price amounted to reciprocity (Field, 2013a, 2013b).

The first step ... is to limit capacity, preventing additional vessels from entering already over-crowded fisheries. The Bellagio Framework, created with the input of world experts, highlights the necessity of capping the current number of vessels and discouraging the addition of new ones. The report noted, "Urgent action is required. Simply put, the global growth in fishing capacity must be curtailed and fleets reduced. The time is ripe to address these problems and their root causes." (Fox and Squires, 2012).

The truth is the expert economic advice of the International Monetary Fund (IMF) based in Washington DC contradicts the expert scientific advice of the International Seafood Sustainability Foundation (ISSF) based in Washington 
DC. The IMF said Tonga's "vast marine resources" provide a profitable business to break the "low development trap" (International Monetary Fund, 2013). The ISSF said to reduce the number of tuna vessels to stop depletion (International Seafood Sustainability Foundation, 2012, 2013). The capital of the United States of America, the wealthiest country, houses the world's experts on money and science. Here were the world authorities liberally dishing out conflicting advice to poor countries deficient in self-reflection, in self-realisation, that irreversible damage is caused by setting double-standards as the global measurement to aspire to.

The real fishy story was America's angst about the post2013 future of the South Pacific Tuna Treaty (SPTT). Since 1987, the United States (US) had entered into an agreement with sixteen states, including Australia and New Zealand, constituting the Pacific Islands Forum Fisheries Agency (FFA). Originally a five year arrangement from 1988 - 1993, the US Treaty has been extended until June the 14th 2013. The objective was for the US to obtain tuna licenses for forty purse seiners to fish within the EEZ of the sixteen Pacific countries. In addition, five more licenses could be obtained for joint US fishing ventures (South Pacific Tuna Treaty, 1987).

A marine conservation argument targeted the US purse seiners, a vessel answerable to overfishing. Bill Fox and Dale Squires remarked that in the tuna industry, "large-scale purse seine vessels are responsible for at least $65 \%$ of the world's tuna catch. The full annual capacity of these vessels is around 4 million tons. Right now, there are very few national or international measures that limit new tuna purse seine construction" (Fox and Squires, 2012). As the US Department of State has made known, its country agenda is not to downsize its purse seine fleet in the Pacific Ocean, but to gain further extension of the Treaty beyond the 2013 expiration date (US Department of State, 2013). 
The United States is currently working with the Forum Fisheries Agency to outline what the nature of the Treaty will look like beyond 2013, and is hopeful we will once again reach an agreement that is mutually beneficial for all of the Parties concerned and promotes sustainability of these valuable resources. (US Department of State, 2013).

In a seashell, the South Pacific Tuna Treaty is not singly about US licenses to fish inside the waters of sixteen Pacific countries in which twelve of these states are geographically south of the equator, outside the northern hemisphere reach of the US military presence in Hawai'i, Guam, and the Marshall Islands (Dufour, 2013; Ewart, 2013; Niendenthal and Chutaro, 2012). The Treaty is geopolitical in nature, securing South Pacific cooperation as Western-friendly allies (Larsen, 2012). Twenty first century international relations have unfolded differently to the twentieth century, particularly in the South Pacific sub-region. China's influence as an aid donor and economic driver in countries such as Fiji, Samoa, and Tonga, is the bone of contention for US security and commercial ascendance in the Pacific region, both north and south of the equator. Today, this is what the West versus East foreign policy battlefield has come down to in the world's largest ocean - fighting over fish. The US-China wrangling for the Pacific sphere of influence converges through one purpose: The license to exploit limited resources, and control these small islands, small worlds, small lives.

All was not lost inside the Tongan state. The senior bureaucrats who were permanent staff compared to the politicians and ministers who came-and-went at every four year election, were well acquainted with knowing that fishing, even in your own fishpond, is political. In this context, when fishing is political it is not entirely scientific or rational. The end product being that the people with little who should benefit the most can be left with the least. Chief Executive for 
the Ministry of Agriculture and Fisheries, Vailala Matoto, exemplified this point in a Radio New Zealand interview.

The ministry's Chief Executive Officer, Vailala Matoto, acknowledges there has been criticism of Tonga's fishing industry following a decline in recent years. He says the ministry hopes to collect better data to prove there is sufficient catch and is working to help local fishing companies. "We are currently working on things like infrastructure and also schemes to make finance available to people who want to get involved but don't have the privilege." Vailala Matoto says he would prefer it if all fishing licenses were granted to locals. (Radio New Zealand International, 2013b).

Matoto's dialogue straddles two setbacks for Tonga's commercial fishing industry. First, he identifies an absence of "infrastructure," signalling to fish and seafood processing plants, and affordable transhipping and air freight services. But the real snag is the lack of financing available to Tongan fishermen to support local business development. He "would prefer it if all fishing licenses were granted to locals," was a testimony to where his loyalty lied (Radio New Zealand International, 2013b). Conversely, the industry is structured to allow foreign investors to dominate the commercial sector of tuna licenses, while Tongans are confined to small-scale fishing and selling locally, as well as the customary practice of gathering seafood for household consumption. 


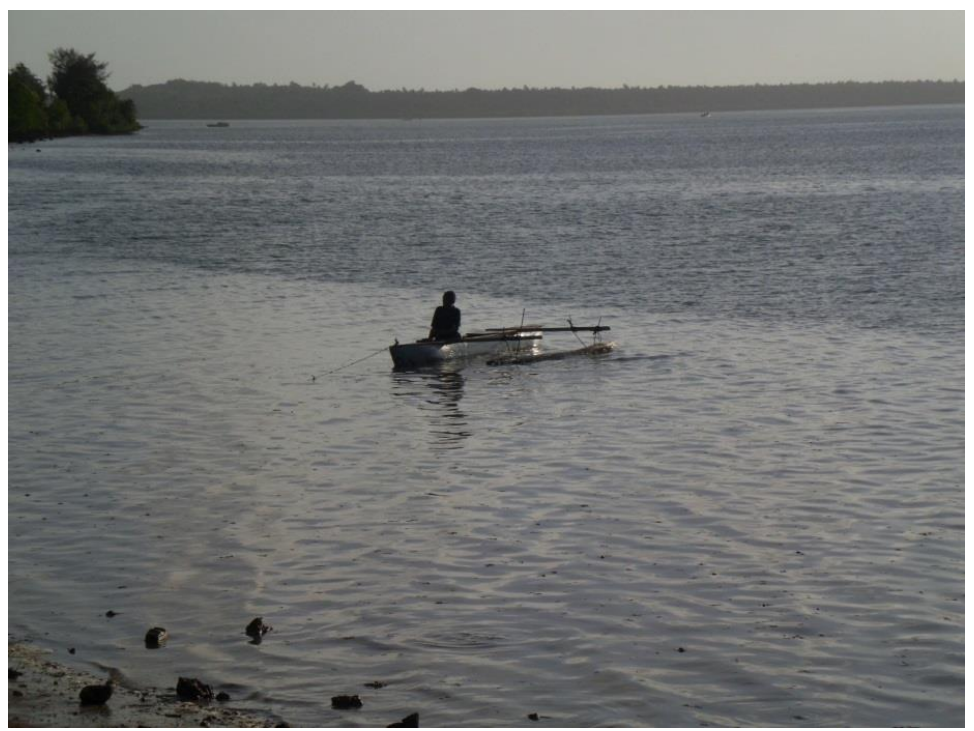

A Tongan boy in a popao, a single-person outrigger canoe used for line fishing in Hahake district, Kingdom of Tonga.

Second, Matoto notes that the "ministry hopes to collect better data to prove there is sufficient catch and is working to help local fishing companies" (Radio New Zealand International, 2013). As a marine scientist, the Chief Executive for Tonga's Ministry of Agriculture and fisheries was critically aware of tuna sustainability measures and that data collection of stock and commercial impact studies are fundamental to state regulation. The glitch is that the Government of Tonga's decision to lift the 2004 foreign vessel moratorium on commercial tuna fishing strategically undermines its national regulatory framework, weakens the state Fisheries Department, and turns a blind eye to regional policy on sustainable tuna management in the South Pacific (Haas, 2013; International Seafood Sustainability Foundation, 2013).

International calls for structural reform of the Tongan state and economy by opening the nation's borders to foreign 
investors ploughed into the method of social and economic exchange propelling Tongan people's values and practices (Wallerstein, 1990). In this small island developing state, the sea had always been open access to all Tongans. The ocean did not discriminate by colour, class, rank, gender, age. Counter to the organisational ethics of small coral atolls and waters that surround them was affording foreigners the privilege of generating income from the sea by alienating local fishermen, by making commercial tuna fishing inaccessible to Tongans.

John Halligan wrote that understanding "the relationship between reform objectives and outcomes can be difficult" business (Halligan, 1997). None-so-much as the reform processes of a small island country like the Kingdom of Tonga where the political ambitions of government are mismatched in what is said will be achieved by altering the system of economy to suit the international market, compared to how change affects and disaffects the everyday livelihoods of ordinary Tongans.

The relationship between reform objectives and outcomes can be difficult to establish. ...Goals may be ambiguously expressed, and may change as reforms are implemented and experience suggests modifications (Olsen and Peters, 1996). ...There are few reformers who do not invoke efficiency, and more usually accountability appears in some guise, but political rhetoric does not necessarily provide a firm basis for subsequent analysis. In seeking to link reform objectives to the results, there is therefore a range of difficulties. (Halligan, 1997, p. 18).

\section{Tongan fish tales}

On the last Wednesday of January 2013, a Tongan colleague from Auckland and I got to spend a couple of hours talking with Semisi Fakahau at Friends Café, a popular eatery in Nuku'alofa. Semisi's reputation preceded him: A local legend, 
he was Tonga's old man of the sea, a masterful fishing expert with a library of knowledge stored in his memory, recalled in his fish tales.

From Auckland I had emailed Semisi Fakahau arranging to speak with him about Tonga's fishing industry, commercial and customary. When we met it was customary ownership, the way that coastal communities felt about their sea resources his conversation steered towards. Semisi was all for the transfer of responsibility for fisheries management from the state to coastal communities.

In Tonga, people never own the sea. The constitution was limited to dry land, the ownership of dry land. But coastal communities feel that land is extended to the sea. They have a feeling of ownership and belonging with the sea. They feel responsible for the management of sea resources and ecosystems.

\section{Semisi Fakahau}

He was referring to the Tonga Fisheries Management Act 2002. Under this law there were designated coastal communities who had special management areas. The logic was for the people to control and regulate the designated sea area according to a fisheries plan, taking on the role and responsibility that the Tonga Fisheries Department would otherwise perform. 


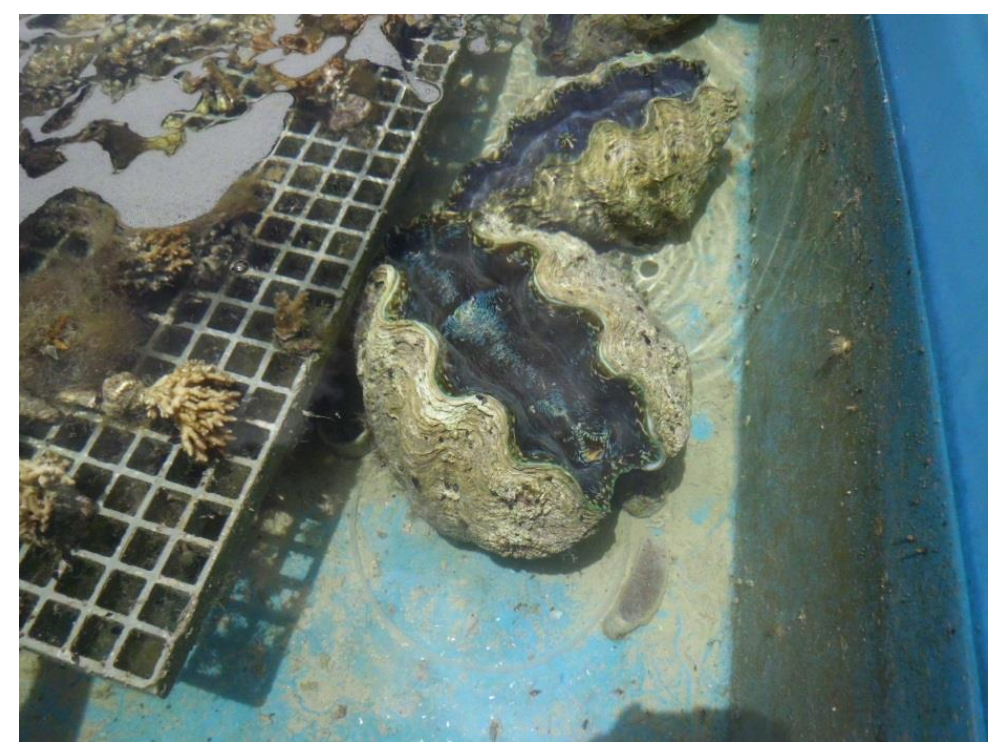

Clams cultivated in seawater tanks at the Fisheries Department, Ministry of Agriculture and Fisheries in Sopu, Kingdom of Tonga.

Eleven years on from the act's inception, seven outer islands from the northern group of Vava'u, the central group of Ha'apai, and off the coast of the southern main island of Tongatapu, had been approved by the Minister of Fisheries to collectively manage the foreshore surrounding their settlements as special management areas. The outer islands were tailor made for this model of marine management, small fishing communities interdependent on their coastal environment for survival.

As his discussion unfolded, Semisi clearly indicated that he considered commercial fishing and customary fishing to be separate and distinct activities. "The danger," as he saw it, was the conflation of the two where coastal communities altered the nature of their customary practice by aggressively pursuing commercial profit made from restricted, and somewhat scarce, sea resources. 
The danger is the commercialisation of fisheries. Sea cucumber is the big money earner for the outer islands. There is a tendency to go for the money because it makes 10-12 million revenue per annum. But it is more important to conserve the resource. In 2012, three people died from diving for sea cucumber. They have to go collect the replenishing stock in deep water because there is no sea cucumber left in the foreshore. I submitted a paper to Fisheries saying that we should save lives and build sea cucumber. A moratorium of five years would replenish stocks and give us time to revise the licensing system and regulations. The thing is to keep the politicians away from it. Sea cucumber gets political and in the system, corruption is involved.

\section{Semisi Fakahau}

In June 2012, the Government of Tonga reneged on the Fisheries Department closure of sea cucumber licensing for three years to rejuvenate depleted stock. Acting against recommendations from its own Ministry for Agriculture and Fisheries, the Tongan state declared that harvesting and exporting sea cucumber was open for business with a shortened season from June to September. Ten licenses were issued to Tongatapu, Vava'u, and Ha'apai exporters at a capped quota of 103 thousand tons for the year (Matangi Tonga Online, 2012b). Matangi Tonga, a local media outlet suggested that it was pressure from the people's representatives in parliament that prompted the government decision to overrule the conservation expertise of its Fisheries Department (Matangi Tonga Online, 2012a). Whatever the motive, it went against scientific good sense to recklessly open and close for business at a political whim when delicately sustaining a fragile sea resource of export value. Mike Batty, the director of the fisheries programme at the Secretariat of 
the Pacific Community explained how good sense had been short changed (Pacific Scoop, 2013).

If we can't manage sea cucumber fisheries, then we can't manage any other coastal fishery in the Pacific. It grows close to shore in shallow water. At a local level sea cucumber are easy to count and easy to monitor exports. It's better for countries to fish sea cucumbers sustainably than to have to close off a fishery every five years. (Pacific Scoop, 2013).

\section{Sea is a security issue}

"In the future, land will become a security issue," said Lord Ma'afu, Minister for Lands and Environment in conversation about Tongan farmers and the difficulties of exporting produce to New Zealand (Brown Pulu, 2011, p. 19). If land in Tonga was a security issue, a highly contested resource fast becoming scarce, hard to obtain, expensive, and increasingly the property right of a few with wealth and privilege, then the sea was a more complex security issue. In Tonga, no one person owned the ocean, but open access to the sea was customary practice. The sea was not legislated the same as land, but it was an extension of land, a fertile resource that was both territory and livelihood, guarded and utilised. One human aspiration seemed certain. If the distinct boundary between commercial and customary fishing is not negotiated to allow Tongans equal access to both systems of economy, cash and subsistence, then successive governments will continue to fall prey to "globalization and its discontents" (Stiglitz, 2002). 


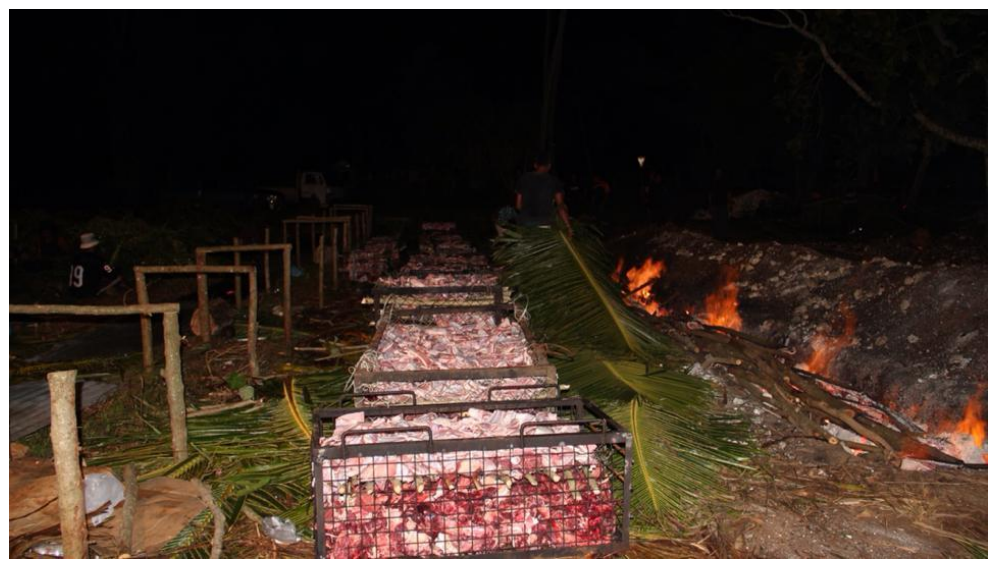

Umu pit, a traditional earth oven at Vaini, Kingdom of Tonga, providing food baskets for Baron Fielakepa's funeral proceedings.

In February of 2013 when my matrilineal cousin Baron Fielakepa, the former noble of Havelu'loto, passed away, Lord Ma'afu, the head of the Ha'a Havea Lahi and noble of Vaini and Tokomololo spent a considerable amount of his personal savings on funeral proceedings. The provision of food baskets for thousands who attended was socially expected. Momentarily I thought he had truly gone nuts, asking him in a half caste Tongan Palangi tone-of-voice, why would he do that? My inquiry said more about me, the privileged ignorance of not being socially expected to possess Tongan etiquette due to cross-cultural contamination.

Ma'afu's answer was straightforward: "This is my responsibility as the head of the clan." His words stuck. Social responsibility was heavy. It was real. It had obligation. It meant duty. It was the practical redistribution of resources for the good of society. And I wondered in the transience of my Tongan New Zealander condition of feeling in between two countries connected by ocean, why the powerful West made it difficult for small island developing states to adapt this system of exchange to national and regional development. By far it 
was constructed of superior moral fabric to what we had received in economic advice and aid assistance.

The one criticism I would contend about Tonga's fishing industry is that government decision-making was bound to be flawed because it debunked scientific literacy. Political pressure to engage foreign investors by the sale of tuna licenses fogged over research-based policy and good sense. The "free market fundamentalists" of the International Monetary Fund (IMF), as Joseph Stiglitz referred to free market economists, and other monetary monitors such as the Asian Development Bank, disciplined the Tongan state into believing "the price of inequality" is their Third World sentence (Stiglitz, 2012). Put simply, the economic situation for Tongan citizens when the government foregoes the sustainable fisheries advice of its marine scientists for bungling business efforts at getting foreign tuna vessels and exporting sea cucumber, is that the country is penalised and pays "the price of inequality."

Neil deGrasse Tyson's description of "science literacy" is relevant here. It is "the power of inquiry" that inspires human beings to be "scientifically literate." For small islands to inquire, query, question, probe the validity of what is force-fed to us by international powers as "true," demonstrates the will to figure out what is really going on in the world (deGrasse Tyson, 2013).

Science literacy is not knowing the answer. You might know the answer; but that's not what's fundamental. What's fundamental is the capacity to inquire about what's true and what is not in this world. And that is the empowerment. The power of inquiry. To be scientifically literate is to empower yourself to know when someone else is full of shit. (deGrasse Tyson, 2013).

\section{We are still fishermen}

We are paradise burning, welcome!

We are fisherman who don't have any fish to fish 
There is no more fish in the sea

Yet, we are still fisherman

Vaimoana Niumeitolu 


\section{References}

Achebe, C. (2009). The Education of a British-Protected Child: Essays. New York, USA: Knopf Doubleday Publishing.

Arrighi, G., Ahmad, I. and Shih, M. (1999). Western Hegemonies in World-Historical Perspective. In Chaos and Governance in the Modern World System, edited by G. Arrighi and B. J. Silver. Minneapolis, USA: University of Minnesota Press, Pp. 217- 270.

Asian Development Bank. (2013). Pacific Economic Monitor: Growth Outlook. Asian Development Bank Pacific Department, Samoa, Solomon Islands, Philippines, Tonga, Papua New Guinea, Vanuatu, Fiji, Sydney, Kiribati, March, Pp. 1-36.

Bellagio Framework. (2010). Bellagio Framework for Sustainable Tuna Fisheries: Capacity controls, rights-based management and effective MCS. Conference on the Allocation of Property Rights in Global Tuna Fisheries, Cordoba, Spain, May 25-29, Pp. 1-8.

Brown Pulu, T. (2011). Shoot the Messenger: The Report on the Nuku'alofa Reconstruction Project and Why the Government of Tonga Dumped It. Kingdom of Tonga: Taimi Publishers.

Brunsson, N. and Sahlin-Andersson, K. (2000). Constructing Organizations: The Example of Public Sector Reform. Organization Studies, 21 (4): 721-746.

Chatterjee, P. (1994). The Nation and Its Fragments: Colonial and Postcolonial Histories. New Jersey, USA: Princeton University Press.

Davis, K. (2012). F@\#\$ I Look Like. Hip Hop TVent, You Tube, Philadelphia, USA, January 27. Retrieved from

http://www.youtube.com/watch?v=7NISakKDA_A

deGrasse Tyson, N. (2013). The Nerdist, by Chris Hardwick, iTunes Audio Podcast, Apple, Cupertino, California, USA, March 29. Retrieved from

http://metousiosis.com/2012/11/04/neil-degrasse-tyson-quote/

Emberson, T. (1998). Development Prospects and Constraints of Domestic Fisheries Enterprises - A Case Study of 'Alatini Fisheries, Tonga. Workshop on Economic Strengthening of Fisheries Industries in Small Island Developing States in the South Pacific, Apia, Samoa, September 14-18. Food and Agriculture Organization of the United Nations, FAO Fisheries Report No. 596 Supplement, Pp. 51-57.

Ewart, R. (2013). Marshallese film to hit LA. Australian Broadcasting Commission: Radio Australia. Melbourne, Australia, March 28. Retrieved from

http://www.radioaustralia.net.au/international/radio/program/pacifi c-beat/marshallese-film-to-hit-la/1108378

Fakahau, S. (2013). Personal Correspondence: Fieldnotes of Teena Brown Pulu, Nuku'alofa, Tonga, January 30.

Field, M. (2013a). Taiwanese fishing boats a threat to killer sharks. Stuff New Zealand, Auckland, New Zealand, January 13. Retrieved from 
http://www.stuff.co.nz/environment/8171830/Taiwanese-fishingboats-a-threat-to-killer-sharks

Field, M. (2013b). Chinese plane forces NZ airline out of Tonga. Stuff New Zealand, Auckland, New Zealand, January 16. Retrieved from

http://www.stuff.co.nz/business/world/8183693/Chinese-planeforces-NZ-airline-out-of-Tonga

Fox, B. and Squires, D. (2012). First Steps to Reducing the Capacity to Catch Tuna. International Seafood Sustainability Foundation (ISSF), Washington DC, USA, June 28. Retrieved from

http://iss-foundation.org/2012/06/28/the-first-step-to-reducingcapacity/

Grafton, R. Q., Hillborn, R., Squires, D., Tait, M. and Williams, M. (2010). Handbook of Marine Fisheries Conservation and Management. New York, USA: Oxford University Press.

Haas, A. (2013). Tonga revenue gain from sale of tuna fishing licenses. Tonga NZ, Auckland, New Zealand, January 10. Retrieved from

http://www.tonganz.net/home/tongan-revenue-gain-from-sale-oftuna-fishing-licences/

Halligan, J. (1997). New Public Sector Models: Reform in Australia and New Zealand. Public Sector Reform: Rationale, Trends and Problems, edited by J. Lane. London, United Kingdom: Sage Publications, Pp. 17-46.

Harvey, F. (2013). Overfishing causes Pacific bluefin tuna numbers to drop 96\%. The Guardian, London, United Kingdom, January 9. Retrieved from

http://www.guardian.co.uk/environment/2013/jan/09/overfishingpacific-bluefin-tuna

International Monetary Fund. (2013). International Monetary Fund: Press Release No 13/92: IMF Concludes the 2013 Article IV Consultation Mission to the Kingdom of Tonga. International Monetary Fund, Washington DC, USA, March 26.

http://www.4-traders.com/news/IMF-International-Monetary-FundPress-Release-IMF-Concludes-the-2013-Article-IV-ConsultationMi--16582435/

International Seafood Sustainability Foundation. (2012). ISSF Stock Status Ratings 2012: Status of the World Fisheries for Tuna: ISSF Technical Report 2012-04B. Washington DC, USA, December, Pp. 1-86.

International Seafood Sustainability Foundation. (2013). An Evaluation of the Sustainability of Global Tuna Stocks Relative to Marine Stewardship Council Criteria: ISSF Technical Report 2013-01 by J. E. Powers and P. A. Medley. Washington DC, USA, February, Pp. 1-252.

Kamali, D. (2011). Tales, Poems, and Songs from the Underwater World. Auckland, New Zealand: Anahera Publishers.

Kingdom of Tonga. (2002). Tonga Fisheries Management Act: Act 26 of 2002. The King and the Legislative Assembly in the Legislature of the Kingdom, October 22, Pp. 1-69. 
Kingdom of Tonga. (2011). The Fisheries Act 1989 (Regulation 28): Locally Based Foreign Fishing Vessel License. Minister of Fisheries, Government of Tonga, Nuku'alofa, Kingdom of Tonga, August 30.

Larsen, E. (2012). Fish and Foreign Policy: Renegotiating the South Pacific Tuna Treaty. Center for Strategic and International Studies: Asia Policy Blog, Washington DC, USA. March 26. Retrieved from

http://cogitasia.com/fish-and-foreign-policy-renegotiating-the-southpacific-tuna-treaty/

Matangi Tonga Online. (2011a). Tonga Opens Up Tuna Fishing to Licensed Foreign Vessels. Matangi Tonga Online, Nuku'alofa, Kingdom of Tonga, October 17. Reprinted in TNews, Auckland, New Zealand. Retrieved from

http:/ / www.tnews.co.nz/forum/showthread.php?tid=6248

Matangi Tonga Online. (2011b). Tuna Association: Tonga's Export Fishing Industry 'Dead!' Matangi Tonga Online, Nuku'alofa, Kingdom of Tonga, December 16. Reprinted in Pacific Islands Report, East West Center, Honolulu, Hawai'i, USA. Retrieved from http://pidp.org/archive/2011/December/12-19-08.htm

Matangi Tonga Online. (2012a). Tonga lifts ban on sea cucumber fisheries under pressure from MPs. Matangi Tonga Online, Nuku'alofa, Kingdom of Tonga, August 3.

http:/ / matangitonga.to/2012/08/03/tonga-lifts-ban-sea-cucumberfisheries-under-pressure-mps

Matangi Tonga Online. (2012b). 10 Licenses Issued for Tonga Sea Cucumber Harvest. Matangi Tonga Online, Nuku'alofa, Kingdom of Tonga, September 19. Reprinted in Pacific Islands Report, East West Center, Honolulu, Hawai'i, USA. Retrieved from

http://pidp.eastwestcenter.org/pireport/2012/September/09-20$\underline{17 . h t m}$

Matangi Tonga Online. (2013). Tonga Foreign Fishing License Fees: A Teardrop in the Ocean. Matangi Tonga Online, Nuku'alofa, Kingdom of Tonga, January 8. Reprinted in Pacific Islands Report, East West Center, Honolulu, Hawai'i, USA. Retrieved from

http://pidp.eastwestcenter.org/pireport/2013/January/01-0809.htm

Niedenthal, J. and Chutaro, S. (2012). Ainkien Jidjid ilo Bon (The Sound of Crickets at Night). Microwave Films, Majuro, Republic of the Marshall Islands, September 14. Retrieved from

http://www.microwavefilms.org/

Niumeitolu, V. (2010). Tongan (American) Creation Myth. Blackmail Press, Volume 31: Marginalization, Auckland, New Zealand. Retrieved from

http:/ / www.blackmailpress.com/VM31.html

Pacific Media Centre. (2012). Tonga: Government to launch new weekly newspaper. Pacific Media Centre, Auckland University of Technology, New Zealand, April 29. Retrieved from

http://www.pmc.aut.ac.nz/pacific-media-watch/tonga-governmentlaunch-new-weekly-newspaper-7913 
Pacific Scoop. (2013). Sea cucumber income could double for Pacific countries: Press Release - Secretariat of the Pacific Community (SPC). Reprinted in Pacific Scoop, Auckland University of Technology, Pacific Media Centre, Auckland, New Zealand, March 7. Retrieved from

http:/ / pacific.scoop.co.nz/2013/03/sea-cucumber-income-coulddouble-for-pacific-countries/

Radio New Zealand International. (2013a). 12 More Tuna Vessels to Operate in Tonga During 2013. Radio New Zealand International, Auckland, New Zealand, January 2. Reprinted in Pacific Islands Report, East West Center, Honolulu, Hawa'i, USA. Retrieved from

http://pidp.eastwestcenter.org/pireport/2013/January/01-0309.htm

Radio New Zealand International. (2013b). Tonga government aims to revive fishing industry. Radio New Zealand International, Auckland, New Zealand, January 16. Retrieved from

http:/ / www.rnzi.com/pages / news.php?op=read\&id=73414

South Pacific Tuna Treaty. (1987). Treaty on Fisheries between the Governments of Certain Pacific Island States and the Government of the United States of America: South Pacific Tuna Treaty (SPTT). Port Moresby, Papua New Guinea, April 2. Retrieved from

http://www.jus.uio.no/english/services/library/treaties/08/802/south-pacific-tuna.xml

Stiglitz, J. (2002). Globalization and Its Discontents. New York, USA: W. W. Norton and Company Incorporated.

Stiglitz, J. (2012). The Price of Inequality. New York, USA: Penguin Books.

TNews. (2011). Tonga Opens Up Tuna Fishing to Licensed Foreign Vessels. Reprinted from Matangi Tonga Online, Nuku'alofa, Kingdom of Tonga, October 17. Retrieved from

http://www.tnews.co.nz/forum/showthread.php?tid=6248

Tonga Government Portal. (2013). Tonga Public Enterprises - Board Members. Ministry of Information and Communications, Nuku'alofa, Kingdom of Tonga, March 29. Retrieved from

http://www.mic.gov.to/government/got/4067-tonga-publicenterprises-board-members

US Department of State. (2013). South Pacific Tuna Treaty. United States of America Department of State, Washington DC, USA, March 31. Retrieved from

http://www.state.gov/e/oes/ocns/fish/bilateral/c33153.htm

Wallerstein, I. (1990). Culture as the Ideological Battleground in the Modern World System. In Global Culture: Nationalism, Globalization and Modernity, edited by M. Featherstone. London, United Kingdom: Sage Publications, Pp. 31-56.

\section{Photographs}

Kolomotu'a, Kingdom of Tonga, Teena Brown Pulu, 2013.

Nuku'alofa Waterfront, Kingdom of Tonga, Teena Brown Pulu, 2013.

Nuku'alofa Waterfront, Kingdom of Tonga, Teena Brown Pulu, 2013. 
Nuku'alofa Waterfront, Kingdom of Tonga, Teena Brown Pulu, 2013.

Hahake District, Kingdom of Tonga, Teena Brown Pulu, 2013.

Sopu, Kingdom of Tonga, Teena Brown Pulu, 2013.

Vaini, Kingdom of Tonga, Tevita 'Unga Ma'afu, 2013.

\section{Tongan glossary}

Palangi European, general reference to white person/people.

Umu A traditional earth oven. 